It is the policy of the University of California (UC) and the UC Division of Agriculture \& Natural Resources not to engage in discrimination against or harassment of any person in any of its programs or activities (Complete nondiscrimination policy statement can be found at http://ucanr.edu/sites/ anrstaff/files/187680.pdf )

Inquiries regarding ANR's nondiscrimination policies may be directed to Linda Marie Manton, Affirmative Action Contact, University of California, Agriculture and Natural Resources, 2801 Second Street, Davis, CA 95618, (530) $750-1318$.
University of California

Agriculture and Natural Resources

California Agriculture

1301 S. 46th Street

Building 478, MC 3580

Richmond, CA 94804

calag@ucanr.edu

Phone: (510) 665-2163

Fax: (510) 665-3427

\title{
Available from ANR
}

\section{California Master Gardener Handbook, Second Edition}

D uring winter's long nights and long-awaited rains, gardeners at last can take a moment to reflect on what worked well over the last year and what didn't. It's a time for pruning and planning, and gardeners are aided this year by UC ANR's new California Master Gardener Handbook (2nd ed.).

Originally a loose-leaf collection of handouts accumulated from years of UC Master Gardener trainings, the Master Gardener Handbook was first published as a bound edition in 2002. UC Cooperative Extension Environmental Horticulture Advisor Dennis R. Pittenger worked for years with an array of other UC professionals and Master Gardener volunteers, combing through program training materials, handouts and notes to bring together an authoritative, comprehensive reference for California gardeners. To say the 2002 release was well-received would be an understatement - within two months UC had to order a second printing, and it's been a steady top-seller ever since.

Now, a dozen years later, a new and expanded edition is available: 756 pages of completely revised and updated information, with new color photos and illustrations. Like all UC ANR publications, the new California Master Gardener Handbook has gone through intensive academic peer review to ensure techni-

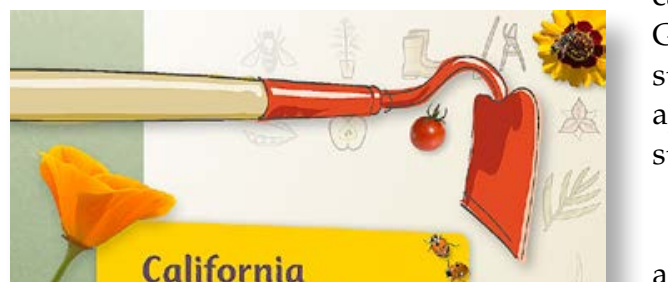
Master Gardener Handbook second Edition

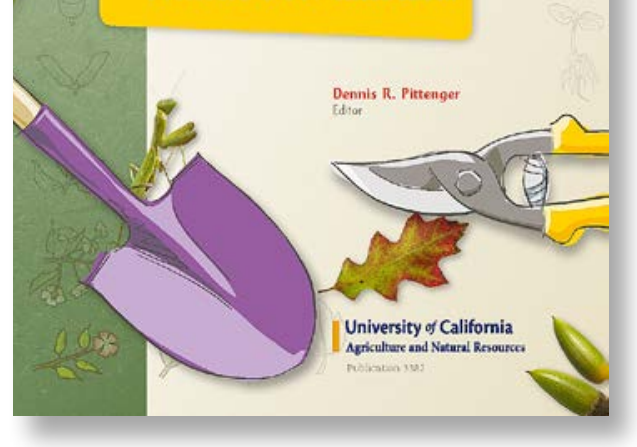
cal soundness. And like the UC Master Gardener program, it's practical and straightforward, with techniques and approaches gardeners can easily understand and apply in their own garden.

You'll find valuable guidance on all aspects of

- lawn and decorative landscape care

- backyard fruit and nut trees

- low-water irrigation

- vegetable gardening

- plant pest and disease management

- and much, much more

This new edition is a must-have for every gardener's bookshelf.

California Master Gardener Handbook (2nd ed.), ANR Publication No. 3382, 756 pp, $\$ 37$

\section{To order:}

Call (800) 994-8849 or (510) 665-2195

or go to http://anrcatalog.ucanr.edu 